\title{
Legal Protection of Contract Workers in the Work Agree- ment in Jayagiri Hotel
}

\author{
Feranika Anggasari Jayanti*, Johannes Ibrahim Kosasih, and I Ketut Widia \\ Universitas Warmadewa, Denpasar-Bali, Indonesia \\ *Email: feranikaanggasari@yahoo.com
}

Published: 30/09/2021

How to cite (in APA style):

Jayanti, F, A., Kosasih, J, I., Widia, I, K. (2021). Legal Protection of Contract Workers in the Work Agreement in Jayagiri Hotel. Jurnal Hukum Prasada, 8(2), 78-88. doi: https://doi.org/10.22225/jhp.8.2.2021.78-88

\begin{abstract}
The development of the tourism industry in Bali causes the high competitiveness of classy hotels such as the Jayagiri Hotel and has an impact on the income aspect of the hotel business, in this case the company's income and leads to legal protection of the rights and obligations given to its workers. This study aims to examine the contractual relationship between contract workers in a work agreement at Jayagiri Hotel and to examine the legal protection can be given for contracts made by the parties and obstacles are experienced by workers in obtaining their rights and obligations. The method used in this study is normative and empirical research method. The results of this study showed that the employment agreement between contract workers and the Hotel has not yet provided a good working relationship so that the application of Law No. 13 of 2003 concerning Employment has not been accommodated. This is due to the entry into force of the standard contract agreement in Jayagiri Hotel which has not provided a balanced position in the same position between workers and employers. Employers as employers always have a higher bargaining position than workers, so the formulation of work agreements in Law No. 13 of 2003 concerning Employment has not been properly accommodated to protect workers' rights and cannot yet prosper workers in accordance with the mandate of the Act.
\end{abstract}

Keywords: certain period employment contract workers; jayagiri hotel; legal protection

\section{INTRODUCTION}

National development is one thing that is very important for a country, especially in some developing countries; Indonesia is one of the developing countries. National development is a series of sustainable development efforts consisting of the entire life of the nation and state to realize the national development goals listed in the 4th century of the Preamble of the 1945 Constitution of the Republic of Indonesia. To realize the achievement of national development goals, strong economic growth is needed. Strong national economic growth is inseparable from the contribution to the improvement of economic sectors and sub-sectors. Tourism is one of the sectors that play a role in the process of regional development in contributing to increasing the income of a region and society through the development and utilization of resources and regional tourism potential that is expected to contribute to economic development. When viewed in terms of economic tourism can be useful as a source of tax income through hotels that have been built, so that economic growth occurs through businesses that support tourism. From a social perspective it can be seen through the exchange of incoming social values. While in terms of culture has an influence that is introducing culture to foreign tourists to be known internationally and cultural exchanges so as to develop the tourism sector in certain areas.

The success of the development of a region's tourism sector can be illustrated by how many tourists visit the region and vice versa. There is support for the allocation of funds 
from the government each year and investments made by the private sector to support facilities in the fields of production, services and accommodation which will be directly or indirectly needed by tourists so that they can support increased tourist visits. The size of the investment made will affect employment opportunities and employment. With greater investment, employment will increase, employment opportunities increase and employment will also increase, and then community income will increase so that community welfare can be achieved. According to Mbaiwa (2005) in the journal Siti Maria, the growth of hotels and restaurants, the number of tourists and the level of income have a positive effect on absorption of the workforce. Manpower as one of the factors that play an important role in advancing the tourism sector, especially in the service-based sector that plays a role in creating successful work (Maria, 2016). Labor according to Article 1 number 2 of Law Number 13 of 2003 concerning Manpower, namely:

"Manpower is every person who is able to do work to produce goods and/or services both to meet their own needs and for the community".

Apart from legislation, several experts provide an understanding of labor, including: Payaman Simanjuntak which provides an understanding of manpower or manpower includes people who are already or who are working, who are looking for work and who do other work such as school and household care (Husni, 2010). What the worker meant is any person who works for a wage or other forms of remuneration (Asyhadie, 2013). Workers here are both workers who work because they open their own business or workers who work in a work relationship or under the orders of someone who gives work.

Workers who do work because of an employment relationship or under the orders of someone who gives work must first enter into an employment agreement, because an employment agreement is the beginning of an employment relationship made on the statement of ability between the employee and the employer (employer), an employment agreement can be made verbally and in writing. Work agreement according to Article 1601 a of the Civil Code states that the relationship between workers and employers is the relationship of subordinates and superiors as well as the existence of the authority of the command, a certain time and the existence of wages so that it distinguishes from other agreements (Oetomo, 2004). The purpose of the employment agreement is to achieve a balance in terms of employment. The duration of an agreement is determined by both parties which can be stated in the work agreement. In a work agreement, there are two types of agreements, namely the Time and Time Agreement, which distinguishes the agreement as the Time and Time Agreement is a work agreement between the worker and the employer to establish a permanent employment relationship, while the Time and Time Agreement is a work agreement between the worker and employers to enter into temporary or contractual work relationships.

The province of Bali is a province in Indonesia whose capital city is Denpasar; geographically Bali is caught between Java and Lombok. Bali has the nicknames of the Island of the Gods and Thousand Temples Island. Bali Province is one area that has many beautiful natural panoramas with a variety of unique cultural arts. Bali has huge potential as one of the tourist destinations ranging from the sea, mountains, rice fields and conditions of the region that are thick with its social culture (banjar system), confidence and trust (Tri Kayangan), patterns of agricultural management (subak system) and others called social capital. This social capital is quite unique, because it is rarely owned by other regions. Various tourism supporting facilities and infrastructure began to be established in Bali. Until now, Bali has more than 112,000 hotel rooms consisting of tourist cottage classes, jasmine to 5 (five) stars (Badan Pusat Statistik Provinsi Bali (Statistics of Bali Province), 2017). The number of developing hotels in Bali, both hotels that are well equipped to local hotels that do not have adequate facilities offers many choices to tourists that are tailored to the needs of tourists in the facilities provided by the hotel. This results in high competitiveness for hotels that are still of ordinary class or jasmine class, which will have an impact on the aspect of hotel business income, in this case corporate income and lead to legal protection of the rights and obligations granted to workers or workers.

Jayagiri Hotel as one of the second-class jasmine hotels engaged in tourism located in the city of Denpasar which is located on Jalan Imam Bonjol No. 341xx. The types of 
workers available at the Jayagiri Hotel include permanent workers and contract workers. The contract worker system is used by Jayagiri Hotel because it has a good level of budget efficiency for management. At Jayagiri Hotel making work agreements do not apply the principles contained in the law of the agreement as a whole. So that in the clause of the work agreement, do not pay attention to guarantees and protection of workers' rights to get a job and a decent wage, the workload provided is almost the same or even heavier than the permanent employees and there are some jobs that are not explained in detail what exactly is the job what the worker will do, and so on. This raises many problems in its implementation because it is not based on harmony with all the principles contained in the treaty law that is not in accordance with the Civil Code, Law Number 13 of 2003 concerning Labor.

There are some similar previous studies that conducted a study about legal protection of contract workers. Albertin A. (2018) in his study, about Legal Protection towards Workers under Collective Labor Agreement, showed that the validity of enactment of collective labor agreement refers to its relation with legal validity of a norm in the principle of legislation lex superior derogate lex impriori, so that the labor laws is enacted, but not apart from the role of labor ministerial regulations. The validity of the legitimate terms of an agreement is also needed to underlie a collective agreement. The legal protection that can be applied for trade union is in the form of supervision as well as legal protection both preventive and repressive outlined in the collective labor agreement content. Furthermore, Marselli \& Wahyuningsih (2018) in their study, identify and analyze the Implementation of the Employment Agreement in the Specific Time (PKWT) At the National Land Agency of Kendal, and the forms of legal protection for workers at National Land Agency of Kendal with the Specific Time of Work Agreement. The results of their study revealed that implementation of the Employment Agreement in the Specific Time (PKWT) at the Land Office of Kendal by implementing probation on each worker who recruits including contract workers. Which it is not supposed to apply probation at a certain time and labor agreements remain to be done if the employment agreement becomes null and void. (2) The legal protection of workers / laborers at Specific Time Work Agreement (PKWT) employee in practice has not run optimally, given the frequent violations, because of the vagueness of the rules on the implementation of the Employment Agreement for specific time periods, in providing protection against labor law for employees in the Land Office of Kendal. Another similar study also conducted by Wijayanti (2018) examined about Effectiveness of Legal Protection on Employees/Labours in a Fixed-Term Employment Contract in Golden Tulip Bay View Hotel \& Convention-Bali, showed that a number of irregularities occur in the implementation of PKWT rules since they do not comply with or are even not referred to Law Number 13 of 2003 concerning Employment. The obstacles faced in the implementation of legal protection for employees/labour under PKWT at Golden Tulip Bay View Hotel \& Bali Convention are Juridical and Non-Juridical barriers. Therefore, legal protection for the employees under PKWT at Golden Tulip Bay View Hotel \& Convention-Bali is not sufficient. Thus, based on the background and the previous studies above, it can be stated that a study about Legal Protection of Contract Workers in the Work Agreement needs to be discussed. Hence, the purpose of this study is to examine the contractual relationship between contract workers in a work agreement at Jayagiri Hotel and to examine the legal protection can be given for contracts made by the parties and obstacles are experienced by workers in obtaining their rights and obligations.

\section{METHOD}

The method applied in this study is normative and empirical research method. Normative legal research is conducted by reviewing the Law and other regulations concerning employment in all aspects related to the subject matter studied, whereas empirical legal research is conducted by examining the contractual suitability made in the Jayagiri Hotel and contract workers with those stipulated in the Act Law No. 13 of 2003 concerning Manpower, as well as legal protection and constraints which are the cause of the inhibition of contract workers to obtain their rights that should be obtained. Furthermore, the approach used in this study is the legislation (statue approach) and conceptual approach, meanwhile the data of this study used primary and secondary data. Primary data 
is obtained by conducting interviews with resource persons at the Jayagiri Hotel and secondary data is obtained from in the form of primary legal materials, namely the Indonesian Constitution, the Civil Code and Law Number 13 of 2003 concerning Employment.

\section{DISCUSSION}

\section{Contractual Relationships between Contract Workers in a Work Agreement at Jayagiri Hotel}

Contractual relationships occur because of an agreement that precedes the legal relationship. An agreement occurs based on an agreement that has been reached by both parties, and gives rise to rights and obligations. According to article 1313 the Civil Code states that, an agreement is an act by which one or more people commit themselves to one or more people. An employment agreement is carried out by involving two parties, namely the employer (the employer) with the party doing the work (the worker), regarding matters to be promised which are fully entrusted to both parties, namely the employer and the worker. Work agreements have 2 (two) forms, namely work agreements made verbally and in writing. Work agreements should not be made verbally for this era where the development of the business world is increasingly complex so that work agreements should be made in writing in order to provide legal certainty regarding the rights and obligations of each party agreed in the work agreement.

The work agreement is divided into two types, namely the Specific Time Work Agreement and the Unspecified Time Work Agreement. A Specific Time Work Agreement is a work agreement between the worker and the employer to enter a work relationship within a certain period of time or is often called a temporary employment agreement, the status of the employee being a non-permanent worker or contract worker, whereas the Unspecified Work Time Agreement which is a work agreement between the worker and the employer to establish permanent employment relations, the status of the workforce is permanent workers.

The types of work that can use a certain time work agreement according to Article 59 of Law Number 13 of 2003 concerning Employment, namely:

"Work agreements for a certain time can only be made for certain jobs which according to the type and nature or activities of the work will be completed within a certain time, namely:

work that is completed once or is temporary in nature;

work that is expected to be completed in a not too long time and a maximum of 3 (three) years;

\section{Seasonal work;}

Work related to new production, new activities or additional products that are still being tested or explored ".

Indonesian treaty law adheres to the principle of freedom of contract in making agreements, but in work agreements that are in force at the Hotel Jayagiri have a standard format (standard contract) which is made unilaterally by the employer/hotel and not through joint drafting of contract workers and rights listed and worker obligations. Republic of Indonesia Law No. 8 of 1999 concerning Consumer Protection defines standard agreements referred to as standard clauses are any rules or conditions and conditions that have been prepared and stipulated in advance unilaterally by business actors as outlined in a document and / or agreement that is binding and must be fulfilled by consumer. So it can be interpreted that a work agreement made by default is every regulation set forth in the form of a work agreement that has been prepared and stipulated in advance unilaterally by the employer where the conditions are binding and must be fulfilled by workers.

A standardized work agreement by the employer often creates problems in its implementation, because it can be ensured that in designing the format and content of the contract the employer will include an exoneration clause in the agreement, namely: clauses 
that benefit him alleviate or even remove the burden of his obligations which should be the burden (Artadi \& Putra, 2014). The application of exoneration clauses made by the employer in the work agreement results in the employee being severely disadvantaged, commonly known as the abuse of conditions (Undue Influence) (Artadi \& Putra, 2014). Work agreements in standard form also violate the principle of freedom of contract, but with the signing of the work agreement by the employer and the worker, both the employer and the worker are considered to have agreed and accepted all the contents of the work agreement, and then the agreement is valid and binding as a law. The law is based on an agreement between the two parties where this is regulated in Articles $1337-1338$ of the Civil Code.

In Article 50 of Law Number 13 Year 2003 concerning Manpower, it is stated that employment relations are relations between employers and workers based on work agreements. With the employment relationship, both employers and workers have entered into a work agreement and each party has rights and obligations. The rights and obligations of each party must be balanced and have a reciprocal relationship.

The elements of the employment agreement according to Article 1 number 15 of Law Number 13 of 2003 concerning Labor and Article 1601a of the Civil Code that is:

There is an element of work

There is work agreed (work object) in the work agreement, that in the work agreement in the Jayagiri Hotel a work object has been agreed upon by the parties in Article 3 paragraph (1) wherein the employer gives work to the worker as housekeeping.

There is an element of command

That in carrying out work as housekeeping, workers must obey the employer's orders to do work in accordance with the agreement. The order referred to in this element has been arranged by the hotel jayagiri in Article 3 paragraph (2) of the work agreement consisting of: neatness, cleanliness and beauty of the entire area of the Hotel as well as providing other supporting facilities needed by guests while in the hotel and company regulations which must be obeyed and carried out by workers.

There is an element of wages

Wages are an important role in employment relationships (work agreements), this is a reciprocity in the employment relationship of the Jayagiri Hotel to workers who have carried out the duties / obligations listed in the work agreement and company regulations, regarding wages listed in Article 5 of the hotel work agreement jayagiri

There is an element of time period

As a job that is carried out in the implementation within a certain period, of course, in a work agreement containing the time period or the start and end of a work contract. In a certain time agreement that applies at the Jayagiri Hotel, the contract period or period is 1 (one) year from the commencement date and when it expires, if both parties agree to extend the contract, the contract can be extended 1 time and renewed 1 time, this included in Article 2 of the work agreement for a certain time in a Jayagiri Hotel.

Besides having to fulfill the elements of the agreement, a certain time work agreement can be declared valid when it has fulfilled the legal requirements for an agreement in the form of material conditions, in Article 52 paragraph (1) of Law Number 13 Year 2003 concerning Manpower states that the employment agreement is made on the basis of:

Agreement between the two parties;

That the emergence of a working relationship between the Jayagiri Hotel with the worker which resulted in the rights and obligations that must be carried out by each party this arises from the agreement of both parties.

The ability or ability to do legal actions;

A person who is deemed capable of making an agreement if the person concerned is old enough where the minimum age of the worker is at least 21 (twentyone) years in 
accordance with the provisions of Article 330 of the Civil Code, this is stated in Article 3 paragraph (2) of the Regulation Company.

The work agreed upon;

As already explained in relation to the elements of the work agreement, there is a work element, namely as House Keeping.

The work promised is not contrary to public order, decency and applicable laws and regulations.

Whereas in the work agreement in force in the Jayagiri Hotel the element of work listed is a form of work in the field of service play that does not conflict with the laws and regulations.

The format of the Specific Time Work Agreement that is adjusted to the formal requirements of article 54 paragraph (1) of Law Number 13 Year 2003 regarding Manpower listed in Jayagiri Hotel is as follows:

There is a date for making a work agreement for a certain time and an agreement between the employer and the worker to enter into an agreement.

Entrepreneur's identity (first party) which contains the name, address, position and represents the Jayagiri Hotel.

Worker identity (Second Party) which contains the name, age, sex, religion and address of the worker.

The term of the work agreement for a certain period of time, in this case stating that this Work Agreement is valid for 1 (one) year and can be extended by both parties, is stated in Article 2 paragraph (1) of the work agreement.

Provisions for work rules, as stated in the Company Regulations at Jayagiri Hotel. Which consists of arrangements for entry and exit, data collection of attendance, attendance, use of hotel telephones, use of mobile phones, processes and conditions for removing goods from hotels, personal belongings of workers, provisions for smoking bans, loss and discovery of goods, personal data of guests, access to the guest room, work area, asking for rewards / extortion, changes in the personal status of workers, and procedures for appearance (Peraturan Perusahaan Hotel Jayagiri, Bab VI Peraturan Tata Tertib dan Disiplin Kerja, Pasal 20, Hal. 9)

Type of work, in the Work Agreement the name or type of work to be performed by the second party is then stated in Article 3 paragraph (1) of the employment agreement.

Provisions for duties, in the Work Agreement the details of the duties and conditions for complying with or complying with all company regulations given are listed in Article 3 paragraph (2) of the employment agreement.

Rights and obligations for workers as second parties, such as the provision of wages / salaries contained in Article 5 in the work agreement, provide training and provide work safety equipment, provide leave, and provide work uniforms listed in Article 6 of the work agreement.

Closing, this agreement is made and signed by both parties in duplicate, each of which has the same legal value.

\section{Legal Protection Given Contracts Made by Parties and Constraints Conceived by Workers in Obtaining Rights and Obligations}

Problems with contract workers are indeed quite varied. This happens because of the many uses of contract labor both from private employers to government agencies, which are considered more efficient and effective. Generally contract workers get lower salaries, social security is received at a minimum, even they are considered only as a factor of production, because if there are new jobs employed and vice versa if there are no jobs then they will be laid off (Termination of Employment). Workers as one of the supporting factors in running a business, of course, must get protection/guarantees for the basic rights of workers and ensure equality and treatment without discrimination on any grounds to realize the welfare of workers and their families while taking into account developments in the 
progress of the business world and the interests of employers. The purpose of worker protection is to provide guarantees for workers' basic rights and equality of opportunity and treatment that does not discriminate or pressure from the strong to the weak. According to Hadjon (1987) there are two things in legal protection, that is:

On preventive legal protection is legal protection given by the government with the aim to prevent before the violation.

Repressive legal protection is the final protection in the form of sanctions such as fines, imprisonment and additional punishment given if a dispute has occurred or a violation has been committed (Hadjon, 1987).

Preventive legal protection provided by the Hotel with the aim of preventing the occurrence of disputes before, this is contained in Article 8 to Article 20 of the Company Regulations which contains working days and hours, leave, rights and obligations as well as hotel regulations. It aims to increase workers' knowledge of the legal field, especially in rights and obligations. While the repressive protection provided by the Hotel in the form of sanctions, fines and other penalties as well as how to resolve disputes, these are listed in Article 32 to Article 43 in the Company Regulation which contains sanctions, Termination of Employment and dispute resolution. Beside the Company Regulations, the work agreements contain several rights and obligations that provide a reciprocal relationship between employers and workers so that both parties in the implementation of work relations, they are bound to those agreed upon in the work agreement or the applicable laws and regulations.

Based on the contents of a particular time work agreement and company regulations which state the rights and obligations of the parties as stated in the specified time work agreement and the Company Regulations in the Jayagiri Hotel, the rights and obligations of contract workers listed in the work agreement in the Jayagiri Hotel, that is:

Workers' rights listed in the employment agreement:

Workers are entitled to receive a salary from the employer of Rp. 2,000,000.00 - (two million rupiah) with an additional meal allowance of Rp. 15,000.00 (fifteen thousand rupiahs) per day when workers come to work and receive overtime pay as much as Rp. $15,000.00$ (fifteen thousand rupiah).

During the engagement period, the employer provides work uniforms for contract workers to wear when carrying out their duties at the Jayagiri Hotel.

Employers provide training and provide occupational safety and health (K3) equipment and self-protection to contract workers.

Workers' obligations stated in the work agreement:

Workers have an obligation to comply with all Company Regulations given by employers.

Workers are obliged to fulfill / carry out their duties as described in the job description or job description provided in the employment contract.

The employee is obliged to keep all information about the employer confidential, whether received or known by him - because of his position, or for other reasons - both as long as the employee works for the employer and after this employment agreement ends.

The worker is obliged to submit all information regarding the employer received or known by him either because of his position, or because of other reasons including all information and data in the form of hard copies, e-mails, diskettes, CDs, USB or in other forms of media; to his boss.

The Jayagiri Hotel company regulation also sets out the rights and obligations of workers and employers as contained in Chapter $\mathrm{V}$ regarding Rights and Obligations stipulated in Article 16 to Article 19, which reads: (Peraturan Perusahaan Hotel Jayagiri, Bab V Hak dan kewajiban, Hal. 7-8). 
Every worker has the right to get duties and work in accordance with the agreed position in the work agreement.

Every worker has the right to compensation in the form of salary, benefits and other income in accordance with his work and responsibilities.

Every worker has the right to time and days of work breaks or leave.

Entitled to get good treatment for himself and his friends in carrying out their respective duties and income in a healthy comparison figure.

Every worker has the right to receive protection for:

Occupational Health and Safety;

Moral and decency;

Treatment in accordance with human dignity and values and religious values.

Good treatment of him through proper appreciation and respect for devotion and optimal work results.

\section{Article 17}

Obligations of workers

Workers carry out their duties and obligations with full awareness and responsibility. hotel.

Workers must work honestly, orderly, carefully and passionately for the benefit of the

Workers must maintain and enhance the integrity, cohesiveness, unity and unity of fellow workers in the hotel Jayagiri.

Creating and maintaining a good work atmosphere.

Use and maintain the belongings of the Jayagiri Hotel as well as possible.

Guiding subordinates in carrying out their duties.

Be and provide examples and good examples of subordinates.

Encourage subordinates to improve their work performance.

Provide opportunities for subordinates to develop their skills and careers.

\section{Article 18}

\section{Entrepreneur's Rights}

The hotel has the right to set annual leave with regard to the interests of workers.

The hotel has the right to give a fine for violating something that is regulated in company regulations.

The Hotel can request compensation from workers in the event of damage to goods or other losses, both belonging to the Hotel or belonging to a third party by the worker because of accident or negligence.

\section{Article 19}

\section{Obligations of entrepreneurs}

The hotel is obliged to provide time off or leave

The hotel is obliged to provide care and treatment

The hotel is obliged to provide a certificate of employment and years of service.

The hotel is obliged to pay wages

In Law Number 13 of 2003 concerning Manpower, in general it has regulated the protection of workers, but lately there have often been many problems arising in society related to workers doing work under the contract system. Where the problem arises is the existence of inequality or incompatibility between the implementation of the applicable laws and regulations with work agreements that are enforced in the community. Where in the work agreement in force in the Jayagiri Hotel there are several things that are considered to have been detrimental to the workers themselves, that is:

Deviations Provisions in the legislation on the implementation of contract workers 'work agreements in Jayagiri Hotel related to workers' rights are as follows: 
First, the issue of wages, that the amount of wages given to workers in article 89 paragraph (1) of the labor law is the minimum wage based on the area or district of the city. Jayagiri Hotel located in the city of Denpasar in accordance with the Bali governor's decision number 2235/03-G/HK/2019 About the regency/city minimum wage in 2020, the regency/city minimum wage of Rp. $2,770,300.00$ but the fact is that contract workers who work in Jayagiri Hotels only get a basic wage of Rp. 2,000,000.00.

Secondly, the issue regarding the period of contract extension in which this matter is regulated in Article 59 paragraph (4) and paragraph (6) of Law Number 13 Year 2003 concerning Manpower, namely a work agreement for a specified period of time of 2 years at most and can be extended once a maximum of 1 year and can be renewed if it has exceeded the grace period of 30 days. However, in the Jayagiri Hotel in the process of extending the contract, it is carried out continuously without any grace period, so that contract workers who have worked more than 5 years using a certain time work agreement should be appointed as permanent workers. However, in the implementation of the worker is still a contract worker.

Third, the issue of benefits, that workers are entitled to permanent and nonpermanent benefits as stipulated in the Circular of the Minister of Manpower Number SE07 / MEN / 1990 concerning Grouping Wages, in applying employment agreements workers should get permanent benefits, non-permanent benefits and benefits holiday. However, at the Jayajiri hotel workers only get temporary benefits in the form of meal allowances based on the attendance of workers and holiday allowances.

Fourth, the problem regarding the exclusion of workers in the labor social security program, that to ensure the welfare of workers, every worker has the right to obtain labor social security provided for in article 99 clause (1) of the labor law, but no contracted workers in a hotel in Jayagiri employers are included in the labor social security program so that it will harm workers.

Deviations Provisions in the legislation on the implementation of contract workers 'work agreements in Jayagiri Hotel related to workers' obligations, namely the work provided by the hotel does not match what has been contained in the work agreement, such as: workers who work as House Keeping, when performing the overtime worker asked to do other parts of the work such as work in the kitchen staff, waiter / waitress, and others.

The implementation of providing protection to workers with work agreements sometimes does not go well as expected or desired by the workers; this is because in its implementation there are obstacles that hinder the achievement of the wishes of the workers. The constraints experienced by contract workers in obtaining legal protection are:

Constraints relating to regulation

That the government legalized certain time labor agreements, and many employers use certain time work agreements, this is considered more practical and efficient because there is no obligation on the part of employers to provide severance when the worker is laid off.

\section{Constraints relating to work agreements}

The work agreement in Jayagiri Hotel uses standard contracts that provide benefits to employers and positions that are detrimental to workers, in addition to the high competition for work, and ignorance of regulations governing employment make workers accept the standard contracts.

The protection of the rights and obligations obtained by contract workers for work agreements that have entered into themselves with employers in the Jagagiri hotel contract work agreement in its implementation have not fully implemented / provided protection that workers should have obtained in accordance with the provisions of law number 13 of 2003 concerning employment. Employers should fulfill basic rights that should be obtained by workers. In the case of the provision of wages, benefits and social security that have not been obtained by contract workers in the hotel Jayagiri. By granting the fulfillment of the rights to workers, it is expected to improve the performance of workers and provide certainty in ensuring health and safety when something unexpected happens in carrying 
out their duties so that in carrying out work relations will achieve a business activity that can increase worker productivity and increase worker income for the common good. In addition, if the company does not provide fulfillment of rights in accordance with the laws and regulations, it will be subject to sanctions in the form of imprisonment and fines to revoke its business license.

\section{CONCLUSION}

Grounded by the results discussed above, thus it can be concluded that 1) the contractual relationship between the employee and the hotel occurs when the work agreement is agreed upon. The work agreement will be binding on both parties, where the contents of the work agreement at the Jayagiri Hotel already contain elements of the work agreement, material requirements and formal requirements as stated in Law Number 13 Year 2003 concerning Employment, that is: a) the elements of the employment agreement in the form of an element of work, an element of order, an element of wages and an element of time. b) Material requirements contain: the agreement of both parties, the ability or ability to carry out legal actions, the existence of the work promised and the work promised must not be contrary to public order, decency and statutory regulations. c) The formal requirements contain the contents of the work agreement. 2) Legal protection given to contract workers and Jayagiri Hotel is divided into 2 types, that is: a) Preventive protection is protection provided by the government with the aim of preventing industrial relations disputes; this is contained in Act Number 13 of 2003 concerning Manpower which is realized in the form of Company Regulations and employment agreements. In Company Regulations which contain working days and hours, leave, rights and obligations are regulated in Article 8 to Article 20 and in the work agreement concerning the validity period of the agreement, duties and placement, working hours, wages, rights and obligations contained in Article 2 to with Article 6. b) Repressive protection is the final protection in the form of sanctions, fines and other penalties, as well as the way in which dispute resolution is given if a dispute has occurred or a violation has been committed. This is contained in Article 32 to Article 43 of the Company Regulations which contains sanctions, Termination of Employment and dispute resolution. The constraints experienced by workers in obtaining their rights and obligations are: a) Constraints related to regulation. In this case the government legalized the system of time-specific employment agreements, so that many employers use workers with a certain time-based employment agreement system, because it is considered more efficient and effective in using workers with a certain time-work agreement system compared to workers with a non-specified time work agreement system. This is done so that employers are not required to pay severance pay when the term of the work agreement expires, the Hotel can reduce labor costs, the Hotel also has no obligation to provide training to workers and does not need to incur costs for recruiting new workers, so that the situation clearly does not provide protection for workers who work with a certain time labor agreement system. b) Obstacles related to work agreements that the work agreement in Jayagiri Hotel is in the form of a standard work agreement, which in its preparation does not involve workers. In a standard work agreement it is not possible for negotiations by the workers, so that any rules or conditions and conditions contained in the work agreement will be more beneficial for the Hotel.

Based on the conclusions above, it can be given some suggestions to several parties. 1) Academically, this research is expected to be able to contribute imliah to the master of law study program postgraduate warmadewa university of Denpasar, a study of the legal protection of contract workers in work agreements at the Jayagiri Hotel. That examines the contractual relationship process between contract workers in a work agreement at the Jayagiri Hotel, giving rise to rights and obligations for both parties and the form of legal protection that can be given for the contracts that the parties have made and the obstacles faced by workers in obtaining their rights. Then this research is expected to be able to provide new references on legal protection for workers in a certain time agreement system. 2) To practitioners and business people of Jayagiri Hotel, represented by the Human Resources Department, to involve workers in making certain time work agreements so that the contents of the work agreement become balanced between rights and obligations which will be implemented by each party. Especially in the Workers' Social Security program for 
workers who are not yet in the work agreement. Because the existence of the Workers' Social Security program actually makes it easy for employers to provide certainty for the guaranteed health and safety of workers that can improve the quality of work of workers. 3) To workers and the general public to increase their self-knowledge, especially to know and understand Law Number 13 of 2003 concerning Manpower, and pay more attention to the contents of work agreements related to rights and obligations that are listed according to or not with the rights that should be obtained. With this knowledge, the workers will know and understand the procedure to fight for their rights. 4) To the Government, to immediately make a Government Regulation as an implementation or guide in the application of Law Number 13 of 2003 concerning Labor. Because the legal norms in Law No. 13 of 2003 concerning Manpower are still a lot of obscurity. The loophole is used by business actors to make work agreements which are naturally in favor of themselves (the employer) in order to have wider authority in the work agreement, so that the application of employment agreements in the field is not in accordance with the legal norms contained in Law Number 13 In 2003 concerning Manpower because there are still many deviations in the provisions that should be the rights of workers.

\section{REFERENCES}

Albertin A, G. (2018). Legal Protection towards Workers under Collective Labor Agreement. Jurnal Notariil, 3(2), 88-96. https://doi.org/https://doi.org/10.22225/jn.3.2.745.88-96

Artadi, I. K., \& Putra, D. N. R. A. (2014). Implementasi Ketentuan-Ketentuan Hukum Perjanjian kedalam Perancangan Kontrak. Denpasar: Udayana University Press.

Asyhadie, Z. (2013). Hukum Ketenagakerjaan Bidang Hubungan Kerja. Jakarta: Rajawali Pers.

Badan Pusat Statistik Provinsi Bali (Statistics of Bali Province). (2017). Jumlah Kamar pada Hotel Non Bintang dan Akomodasi Lainnya Menurut Kelompok Kamar di Bali, 2000-2019.

Hadjon, P. M. (1987). Perlindungan Hukum Bagi Rakyat Indonesia. Surabaya: PT Bina IImu.

Husni, L. (2010). Hukum Ketenagakerjaan Indonesia (Cet. 10). Jakarta: PT Raja Grafindo Persada.

Maria, S. (2016). Dampak Sektor Pariwisata terhadap Kesempatan Kerja Pariwisata di Provinsi Kalimantan Timur. Conference on Management and Behavioral Studies, 632-641. Jakarta: Universitas Tarumanagara.

Marselli, A., \& Wahyuningsih, S. E. (2018). Legal Protection Of Contract Employees Agreement In The Implementation Of Certain Time In Kendal (National Land Agency). Jurnal Akta, 5(2), 491. https://doi.org/10.30659/akta.v5i2.3221

Mbaiwa, J. E. (2005). Enclave Tourism and its Socio-economic Impacts in the Okavango Delta, Botswana. Tourism Management, 26(2), 157-172. https://doi.org/10.1016/ j.tourman.2003.11.005

Oetomo, G. (2004). Pengantar Hukum Perburuhan dan Hukum Perburuhan di Indonesia. Jakarta: Grhadika Binangkit Press.

Wijayanti, R. (2018). Effectiveness of Legal Protection on Employees/Labours in a Fixed-Term Employment Contract in Golden Tulip Bay View Hotel \& Convention-Bali. Jurnal Hukum Prasada, 5(2), 90-99. https://doi.org/https://doi.org/10.22225/jhp.5.2.761.90-99

Peraturan Perusahaan Hotel Jayagiri, Bab V Hak dan kewajiban, Hal. 7-8.

Peraturan Perusahaan Hotel Jayagiri, Bab VI Peraturan Tata Tertib dan Disiplin Kerja, Pasal 20, Hal. 9. 